\title{
Lecithotrophic behaviour in zoea and megalopa larvae of the ghost shrimp Lepidophthalmus siriboia Felder and Rodrigues, 1993 (Decapoda: Callianassidae)
}

\author{
FERNANDO A. ABRUNHOSA, DARLAN J.B. SIMITH, CARLOS A.M. PALMEIRA \\ and DANIELLE C.B. ARRUDA
}

Universidade Federal do Pará (UFPA), Campus Universitário de Bragança, Laboratório de Carcinologia Alameda Leandro Ribeiro s/n, Bairro Aldeia, 68600-000 Bragança, PA, Brasil

Manuscript received on October 25, 2007; accepted for publication on March 25, 2008; presented by ALEXANDER W.A. KELLNER

\begin{abstract}
Food supply is considered critical for a successful culturing of decapod larvae. However, some species may present yolk reserve sufficient to complete their larval development without external food supply (known as lecithotrophic larval development). In the present study, two experiments were carried out in order to verify whether the callianassid Lepidophthalmus siriboia have lecithotrophic behaviour or, if they need external food for their larval development: Experiment 1, larvae submitted to an initial feeding period and Experiment 2, larvae submitted to an initial starvation period. High survival rate was observed in both experiments, in which only 2 megalopae and 1 zoea III died. These results strongly suggest that larvae of $L$. siriboia are lecithotrophic as they have sufficiently large yolk reserve to complete their larval development, while the megalopa stage shows facultative lecithotrophy. The larval periods of each stage of the treatments were quite similar and, despite some significant differences in some larval periods, these can be related probably to larval rearing conditions, abiotic factors or, individual variability of larval health, as well as stress caused to the ovigerous females during embryogenesis.
\end{abstract}

Key words: behaviour, Callianassidae, larval development, lecithotrophy, Lepidophthalmus siriboia, starvation.

\section{INTRODUCTION}

The family Callianassidae is represented by nine genera with several species in Brazil, but only one belongs to the genus Lepidophthalmus (Holmes 1904), the species L. siriboia. This species occurs on the Occidental Atlantic-Florida, Gulf of Mexico, West Indies and Brazil (from Pará to Bahia States) inhabiting submerged galleries in the intertidal zones, in very shallow waters (Melo 1999). It lives in association with a small pinnotherid crab Pinnixa gracilipes in the northeastern region of Pará (Lima et al. 2006). A recent study has reported that this species has a short larval development consisting of three zoeal and a megalopa stages (Abru-

Correspondence to: Prof. Dr. Fernando Araújo Abrunhosa E-mail: faraujo@ufpa.br nhosa et al. 2005). The larvae hatch as prezoea without natatory movements, staying in this phase for approximately 4 hours (Abrunhosa et al. 2005, 2006).

Few studies have been done on the biology of callianassids, mainly those related to their larval biology. The larviculture is recognized as an important instrument in revealing aspects of the crustacean biology. However, for successful larval culture investigations on adequate food and feeding regimes for larvae are indispensable. Thus, the type of food and the favourable period of its addition in the culture are considered critical for the success of larvae and post-larvae development.

On the other hand, some decapod species show lecithotrophic development during their larval development (Anger 1995). They hatch with yolk reserve stored 
in the midgut gland sufficient for the larvae to surpass natural barriers during their development (Anger and Darwirs 1981, Anger et al. 1985, McConaugha 1985, Anger 1995, 1996). In crustacean culture tanks, the addition of live foods may be prejudicial to the larvae in case of lecithotrophy because Artemia nauplii, for example, may deteriorate the water quality causing damages to the health of the larva (Abrunhosa and Kittaka 1997a).

The lecithotrophic behaviour of the Callianassidae larvae has been very little studied. Thessalou-Legaki et al. (1999) reported that larvae of Callianassa tyrrhena hatch with yolk reserves necessary to complete their larval development until megalopa stage even under complete starvation. But, these authors observed that when food is offered, larvae of this species may consume Artemia nauplii during zoeal stages and they concluded that $C$. tyrrhena have a facultative lecithotrophy development. More recently, Abrunhosa et al. (2006), describing the gross morphology of external feeding appendages and foregut of larvae and postlarvae of $L$. siriboia, observed that the mouthparts have a reduced number of setae and the foregut was under-developed. All these structures are fully setose and well-developed in megalopa and juvenile I. These facts strongly suggested a non-feeding behaviour in the zoeal stages although, they are feeding animals in the megalopa and juvenile stages. The present study investigates the effect of starvation on larvae of $L$. siriboia, in order to support the observations reported by Abrunhosa et al. (2006).

\section{MATERIALS AND METHODS}

Ovigerous females of L. siriboia were collected in the Canela Island (Northeast of Pará State, Brazil) with a hand-operated vacuum suction device (yabby pump). In the laboratory, they were maintained in aquaria (10L) containing filtered seawater with constant aeration and muddy-sand substratum (approximately $500 \mathrm{~g}$ was homogeneously added in the bottom) until larval release.

After hatching, the larvae were placed in small recipients (polyethylene, $150 \mathrm{~mL}$ ) and were individually reared. The temperature, salinity and $\mathrm{pH}$ of the cultivation seawater were recorded daily in the recipients. The larvae were reared in salinity 30 , temperature $27-29^{\circ} \mathrm{C}$ and $\mathrm{pH} 8.1-8.3$. The larval development was daily monitored every thirty minutes (day and night) in each exper- iment. The cultivation seawater was renewed everyday. Two experiments were performed where the L siriboia larvae were individually reared:

Experiment 1 - larvae of L. siriboia submitted to an initial feeding period. Four treatments were performed with 10 larvae/treatment, in which they were fed with Artemia nauplii for 1 day (treatment 1), 2 days (treatment 2), 3 days (treatment 3 ) and everyday (control treatment), respectively.

Experiment 2 - larvae of L. siriboia submitted to an initial starvation period. Four treatments were performed with 10 larvae/treatment in which, they were starved for 0 day (i.e. they were not fed - control treatment), 1 day (treatment 1), 2 days (treatment 2) and 3 days (treatment 3), respectively. After the respective period of starvation, the larvae were fed with Artemia nauplii.

\section{STATISTICAL ANALYSIS}

The data analyses of the cumulative larval duration (CLD) of each larval stage (in both, feeding and starvation experiments) were performed in order to verify whether the larval period was affected when the larvae were submitted to different starvation or feeding periods. For the statistical analyses of CLD data the nonparametric Kruskal-Wallis (H-test) was used, after tests for normality and homogeneity of variances (ShapiroWilk and Levene's tests, respectively). The Dunn's test was used for multiple comparisons (Post hoc test) among treatments (including control treatment) belonging to the respective experiments. Significant differences were considered when $P<0.05$. All statistical analysis followed standard techniques (Sokal and Rohlf 1995).

\section{RESULTS}

L. siriboia shows a short larval development, consisting of three zoeal and a megalopa stages. No feeding behaviour was observed in the larvae (from zoea I to zoea III) during these whole experiments. But, after metamorphosis to megalopal stage they became feeding crustaceans. High survival rate was observed in both treatments with initial starvation and feeding periods (see below). 


\section{EXPERIMENT 1: LARVAE SUBMITTED TO AN INITIAL} FEEDING PERIOD

\section{Survival rate and intermoulting periods}

In the first experiment (initial feeding period), the percentage of zoea of $L$. siriboia moulting to megalopa stage was $100 \%$ in all treatments. However, two megalopae died in this experiment before moulting to juvenile I stage ( 1 megalopa in the treatment fed during 2 days and 1 in the treatment fed during 3 days, respectively). In the second experiment (initial starvation period), only one larva died (zoea III) in the treatment that larvae have starved during 2 days. No mortality was observed in other zoeal or megalopal stages.

1. Larvae of L. siriboia fed everyday (Control): The intermoulting period of zoea I, zoea II, zoea III and megalopa were $17 \mathrm{~h}, 33 \mathrm{~h}, 70 \mathrm{~h}$ e $189 \mathrm{~h}$, respectively (Fig. 1).

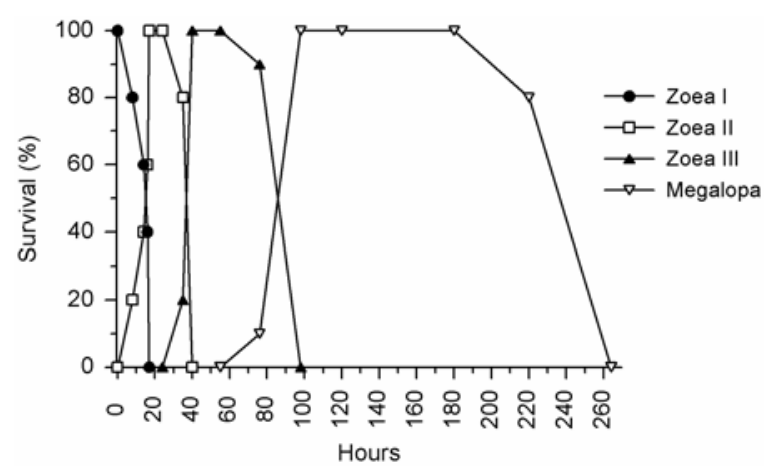

Fig. 1 - Survival (\%) and intermoulting period (hours after hatching) of Lepidophthalmus siriboia larvae reared in the laboratory and submitted to an initial feeding period. In this treatment they were fed everyday (Control treatment).

2. Larvae of L. siriboia fed during 1 day: The intermoulting period were $18 \mathrm{~h}, 31 \mathrm{~h}, 77 \mathrm{~h}$ e $155 \mathrm{~h}$ for zoea I, zoea II, zoea III and megalopa, respectively (Fig. 2).

3. Larvae of L. siriboia fed during 2 days: The intermoulting periods were $15 \mathrm{~h}, 37 \mathrm{~h}, 48 \mathrm{~h}$ e $197 \mathrm{~h}$ for zoea I, zoea II, zoea III and megalopa, respectively (Fig. 3).

4. Larvae of L. siriboia fed during 3 days: The intermoulting period were $20 \mathrm{~h}, 35 \mathrm{~h}, 90 \mathrm{~h}$ e $174 \mathrm{~h}$ for zoea I, zoea II, zoea III and megalopa, respectively (Fig. 4).

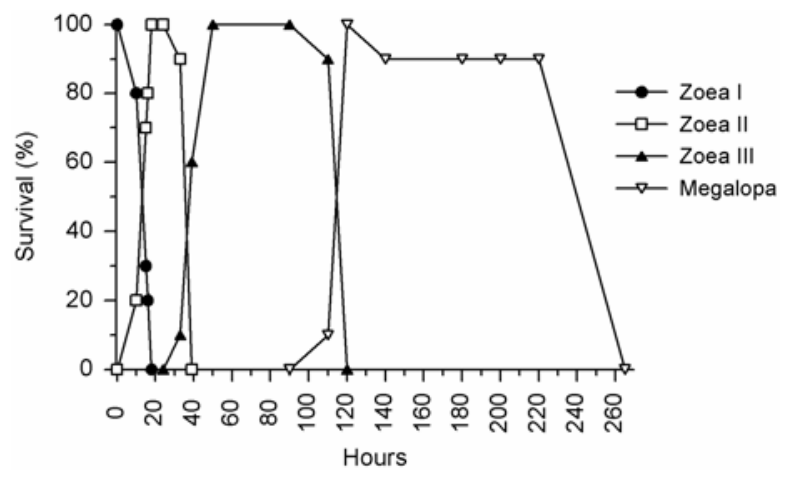

Fig. 2 - Survival (\%) and intermoulting period (hours after hatching) of Lepidophthalmus siriboia larvae reared in the laboratory and submitted to an initial feeding period. In this treatment, they were fed during 1 day only.

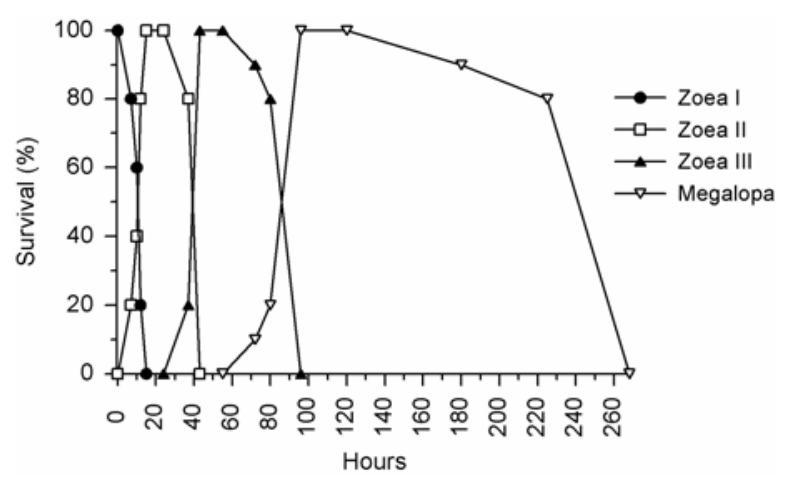

Fig. 3 - Survival (\%) and intermoulting period (hours after hatching) of Lepidophthalmus siriboia larvae reared in the laboratory and submitted to an initial feeding period. In this treatment, they were fed during 2 days only.

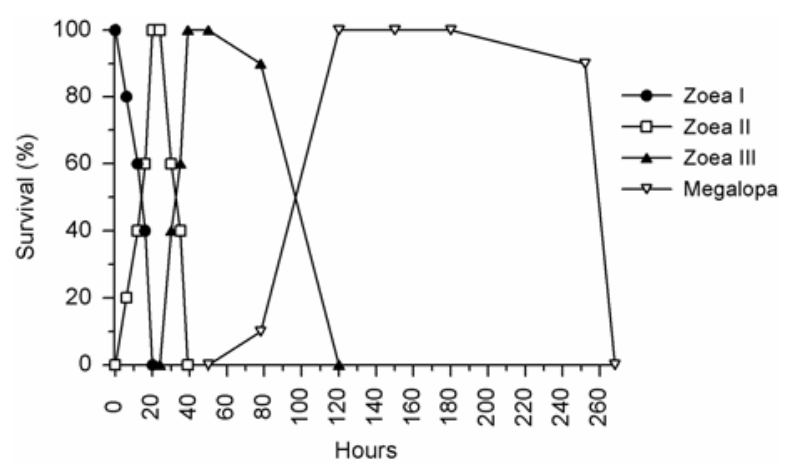

Fig. 4 - Survival (\%) and intermoulting period (hours after hatching) of Lepidophthalmus siriboia larvae reared in the laboratory and submitted to an initial feeding period. In this treatment, they were fed during 3 days. 


\section{Cumulative Larval Duration (CLD)}

For cumulative CLD of zoea I, a significant difference was observed among respective treatments $(H=18.2$; $d . f .=3 ; P<0.05$; Fig. 5). In this larval stage, the cumulative CLD ranged from $6.0( \pm 1.5)$ hours, observed in treatment where larvae of $L$. siriboia were fed everyday, to $8.9( \pm 1.1)$ hours, recorded in the treatment with larvae fed during 2 days. A significant difference $(P<0.05)$ was observed between treatments 1,3 and 4, respectively (Fig. 5).

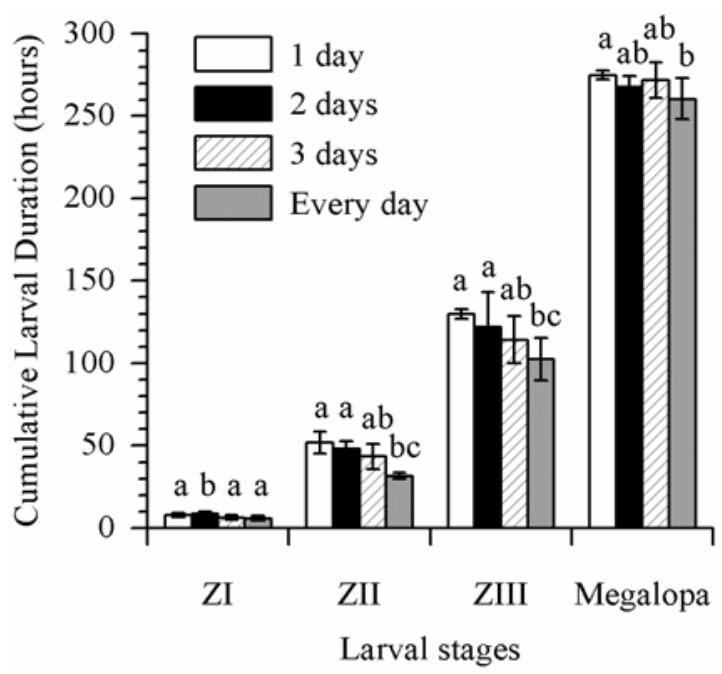

Fig. 5 - Cumulative larval duration in hours (CLD, average \pm standard deviation) of Lepidophthalmus siriboia larvae reared in the laboratory and submitted to an initial feeding period. 1 day (treatment 1), 2 days (treatment 2), 3 days (treatment 3 ) and everyday (control treatment). Significant differences are represented by letters when $P<0.05$ after Dunn's test. Treatments with at least one same letter in common did not differ statistically ( $\alpha=0,05)$. ZI, ZII, ZIII (zoeal stages).

Similar to the previous stage, the cumulative CLD of zoea II, also showed a significant distinction among the treatments $(H=23.9 ; d . f .=3 ; P<0.05$; Fig. 5$)$. The smallest cumulative CLD was recorded in the treatment for those larvae fed everyday ( $31.7 \pm 2.0$ hours) and the largest was observed in the treatment in which larvae were fed during one day (52.0 \pm 6.6 hours). Significant differences $(P<0.05)$ were observed between treatment 4 versus treatments 1 and 2 (Fig. 5).

For zoea III, the cumulative CLD was significantly distinct among treatments $(H=12.4 ; d . f .=3 ; P<$ 0.05 ; Fig. 5). This stage exhibited the smallest cumula- tive CLD in treatment for larvae fed everyday (102.5 \pm 12.8 hours) and the largest in the treatment with larvae fed during one day (129.7 \pm 2.8 hours). With zoea II, significant differences $(P<005)$ were also observed between treatment 4 versus treatments 1 and 2 (Fig. 5).

Finally, for megalopa stage, the cumulative CLD also showed a significant distinction among treatments $(H=8.6 ;$ d.f. $=3 ; P>0.05$; Fig. 5$)$ similar to the early zoeal stages. However, significant differences $(P<0.05)$ were observed only between the treatments 1 and 4 (Fig. 5). The smallest cumulative CLD was $260.6 \pm 12.8$ hours, observed in the treatment with megalopae fed everyday and the largest was $275.0 \pm$ 2.7 hours, recorded in the treatment with megalopae fed during one day (Fig. 5).

\section{EXPERIMENT 2: LARVAE SubmitTed to AN INITIAL STARVATION PERIOD}

\section{Survival rate and intermoulting periods}

Only one larva died (zoea III) in the treatment in which larvae have starved during one day. No mortality was observed in the megalopal stage. Different intermoulting periods were observed in each respective treatment.

1. Larvae of L. siriboia submitted to entire starvation (Control): The intermoulting periods for zoea I, zoea II, zoea III and megalopa were $22 \mathrm{~h}, 71 \mathrm{~h}, 82 \mathrm{~h}$, 191h, respectively (Fig. 6).

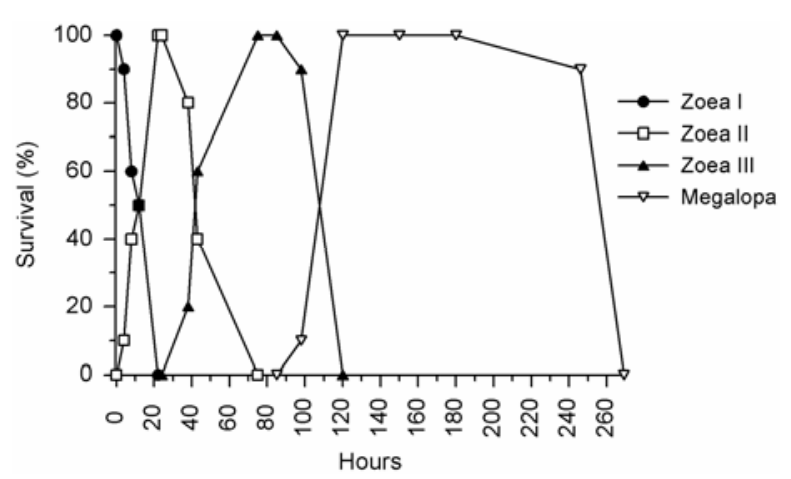

Fig. 6 - Survival (\%) and intermoulting period (hours after hatching) of Lepidophthalmus siriboia larvae reared in the laboratory and submitted to an initial starvation period. In this treatment, they were submitted to entire starvation (Control treatment).

2. Larvae of $L$. siriboia starved during 1 day: The intermoulting periods for zoea I, zoea II, zoea III and 
megalopa were $18 \mathrm{~h}, 30 \mathrm{~h}, 60 \mathrm{~h}, 170 \mathrm{~h}$, respectively (Fig. 7).

3. Larvae of L. siriboia starved during 2 days: The intermoulting periods for zoea I, zoea II, zoea III and megalopa were $16 \mathrm{~h}, 37 \mathrm{~h}, 67 \mathrm{~h}, 176 \mathrm{~h}$, respectively (Fig. 8).

4. Larvae of L. siriboia starved during 3 days: The intermoulting period for zoea I, zoea II, zoea III and megalopa were $19 \mathrm{~h}, 44 \mathrm{~h}, 62 \mathrm{~h}, 183 \mathrm{~h}$, respectively (Fig. 9).

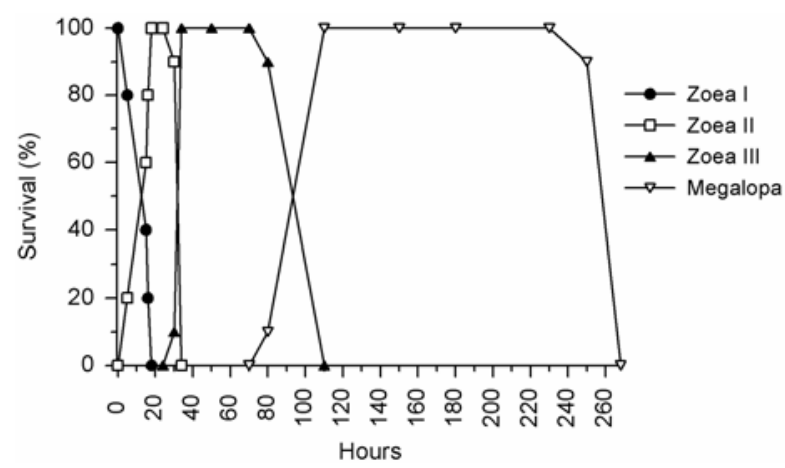

Fig. 7 - Survival (\%) and intermoulting period (hours after hatching) of Lepidophthalmus siriboia larvae reared in the laboratory and submitted to an initial starvation period. In this treatment, they were starved during 1 day.

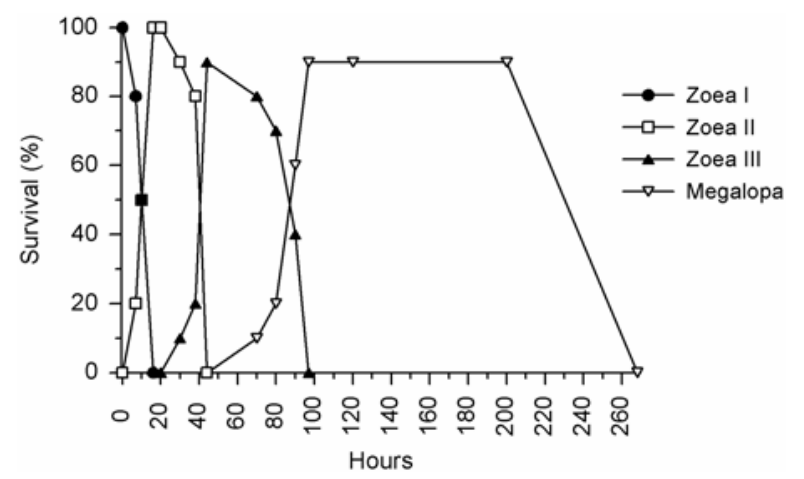

Fig. 8 - Survival (\%) and intermoulting period (hours after hatching) of Lepidophthalmus siriboia larvae reared in the laboratory and submitted to an initial starvation period. In this treatment, they were starved during 2 days.

\section{Cumulative Larval Duration (CLD)}

The different starvation periods for zoea I did not result in significant differences in the cumulative CLD among

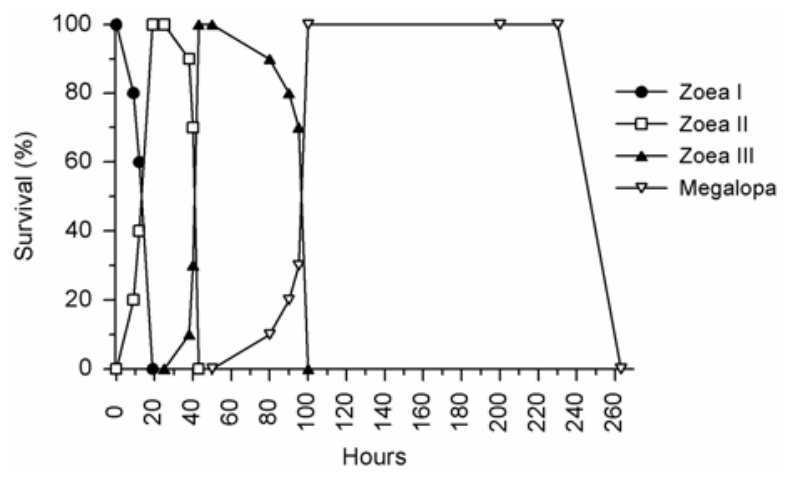

Fig. 9 - Survival (\%) and intermoulting period (hours after hatching) of Lepidophthalmus siriboia larvae reared in the laboratory and submitted to an initial starvation period. In this treatment, they were starved during 3 days.

treatments $(H=1.5 ;$ d.f. $=3 ; P>0.05)$, which showed a cumulative CLD around 7 hours (Fig. 10). In contrast, for zoea II this cumulative CLD presented a significant difference among treatments $(H=20.4$; d.f. $=3 ; P<0.05$; Fig. 10). For this zoeal stage, the smallest cumulative CLD (33.3 \pm 8.4 hours) was observed in treatment with larvae of $L$. siriboia starved during 1 day and the largest (53.5 \pm 8.8 hours) in treatment with larvae starved during 2 days. Of all treatments, only treatments 1 versus 4 and 2 versus 3 were not significantly distinct $(P>0.05)$ (Fig. 10).

The cumulative CLD of zoea III stage was significantly distinct among treatments $(H=16.9 ; d . f .=3$; $P<0.05$; Fig. 10). The smallest cumulative CLD $(111.5 \pm 20.1$ hours) was recorded in the treatment in which larvae of $L$. siriboia were starved during 1 day and the largest (132.2 \pm 2.1 hours) was observed in the treatment with larvae starved during 3 days. For this zoeal stage, significant differences $(P<0.05)$ were only observed between treatments 1 versus 3 (Fig. 10). For cumulative CLD of megalopae stage, no significant differences were observed among the different starvation treatments $(H=3.9 ; d . f .=3 ; P>0.05)$, which values ranged from 261 to 274 hours (Fig. 10).

\section{DISCUSSION}

In the present study, both larvae of L. siriboia submitted to entire feeding and starvation succeeded moult to the megalopa stage. In both, feeding and starvation treatments, the survival rates were quite high. This fact 


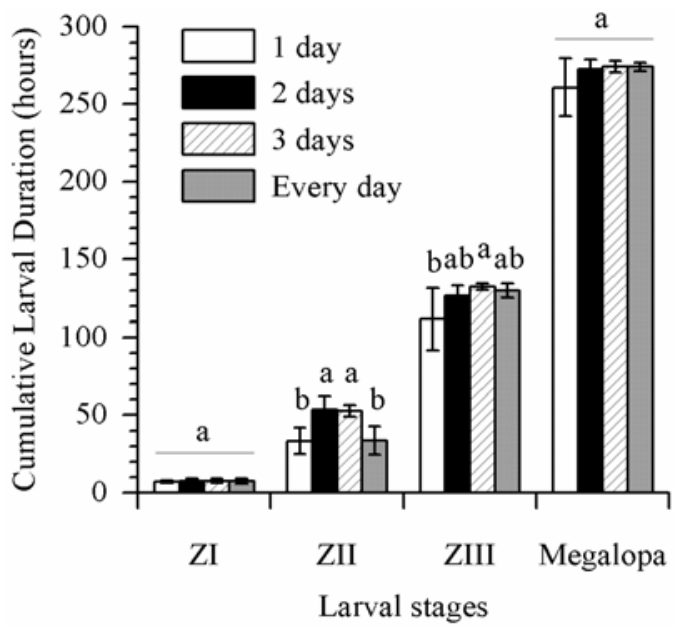

Fig. 10-Cumulative larval duration in hours (CLD, average \pm standard deviation) of Lepidophthalmus siriboia larvae reared in the laboratory and submitted to an initial starvation period. 1 day (treatment 1), 2 days (treatment 2), 3 days (treatment 3 ), no feeding (control treatment). Significant differences are represented by letters when $P<0.05$ after Dunn's test. Treatments with at least one same letter in common did not differ statistically ( $\alpha=0,05)$. ZI, ZII, ZIII (zoeal stages).

strongly suggests a lecithotrophic behaviour in this species. The lecithotrophic behaviour has already been observed for other species of the Lepidophthalmus genus. Nates and Mckenney Jr. (2000) have investigated the biochemical composition of the callianassid L. louisianensis, and revealed that those larvae are adapted for a lecithotrophic life.

Brachyuran crustaceans with extended larval development have no yolk reserve enough to reach the megalopa stage without external food (Abrunhosa and Kittaka 1997a). The opposite case is when a species has abbreviated larval stages and can complete the whole larval development independently of an external food source (Abrunhosa and Kittaka 1997a, b). Studies accomplished with larvae of the semiterrestrial crab Sesarma curacaoense (de Man 1892), in which the larval cycle is short, indicate that they complete their zoeal development without available food. However food is necessary for megalopa to reach juvenile stage (Anger 1995).

Detailed morphological studies on the digestive system of larvae and post-larvae of crustacean decapods have demonstrated a narrow relationship among the morphology of the mouthparts and foregut and feed- ing behaviour of the individual (Abrunhosa and Kittaka 1997a, Abrunhosa et al. 2003, Abrunhosa et al. 2006). These authors observed that puerulus of the spiny lobster and the glaucothoe of king crabs bear maxillae and foregut poorly developed and uncalcified. Thus, they suggested a non-feeding behaviour in the transitory stage of these crabs. This suggestion has been confirmed in culture experiments in the laboratory (Abrunhosa and Kittaka 1997b). Abrunhosa et al. (2006) described detailed morphological features of the mouthparts and foregut of $L$. siriboia and observed that the inner appendages of maxillule, maxillae and maxillipeds are rudimentary, lacking setae, and the foregut has a reduced filter press. These authors suggested a non functionality of these structures and, consequently, no feeding behaviour during zoeal development of this species. The results of the present study support such hypothesis.

According to Abrunhosa et al. (2006), after the metamorphosis to megalopa stage, a drastic morphological change occurs in the mouthparts and foregut of $L$. siriboia. All these structures become specialized, which indicate that food is necessary during this phase. Thus, L. siriboia megalopa may eat a great variety of food (Abrunhosa et al. 2006). However, experiments accomplished in the present study have demonstrated that the L. siriboia megalopae were able to succeed in moulting to juvenile stage without external food. This strongly indicates a facultative lecithotrophy for this species during this stage. Some callianassids were described as having a relatively extended larval development. The Callichirus major, for instance, has been reported with 5 zoeal and a megalopal stages (Strasser and Felder 1999). These authors observed that the external and internal feeding structures are more specialized in the zoea when compared to L. siriboia, indicating that this species is probably unable to surpass the larval period without feeding (Rodrigues 1976). On the contrary, C. tyrrhena has presented an optional lecithotrophy if food is not available in the environment or culture (ThessalouLegaki et al. 1999).

In the first experiment (initial feeding period) of the present study, marked differences were only observed in the cumulative larval duration (CLD) of the zoea II, III and megalopa stages in the treatments with food available for 1 and everyday. The larval periods of each 
stage of the treatments were quite similar and, despite some significant differences were observed during the larval period. This probably can be related to larval rearing conditions, abiotic factors or still, individual variability of larval health, as well as stress caused to the ovigerous females during embryogenesis. Further studies are needed to test other factors on the larval development of the L. siriboia, in order to verify the effects in the survival rate and CLD.

\section{ACKNOWLEDGMENTS}

The authors are grateful to Universidade Federal do Pará and to Conselho Nacional de Desenvolvimento Científico e Tecnológico (CNPq) for supporting this study.

\section{RESUMO}

A alimentação é considerada crítica em cultivo de larvas de decápodes. No entanto, algumas espécies podem apresentar reservas nutritivas suficientes para completar o desenvolvimento larval sem a necessidade de alimentação externa (conhecido como desenvolvimento larval lecitotrófico). No presente estudo, dois experimentos foram realizados para verificar se o callianassídeo Lepidophthalmus siriboia tem comportamento lecitotrófico ou se precisa de alimento externo para completar o desenvolvimento larval: Experimento 1, larvas submetidas a um período inicial de alimentação e, Experimento 2, larvas submetidas a um período inicial de inanição. Em ambos os experimentos, observou-se altas taxas de sobrevivência, com apenas 2 megalopas e 1 zoea III mortos. Estes resultados sugerem fortemente que larvas de $L$. siriboia são lecitotróficas, tendo reservas suficientes para completar o desenvolvimento larval, enquanto o estágio de megalopa apresenta lecitotrofia facultativa. Os períodos larvais de cada estágio nos tratamentos foram bastante semelhantes. No entanto, foram observadas algumas diferenças significantes entre alguns períodos, os quais podem estar relacionados às condições de cultivo, provavelmente devido a fatores abióticos, à variabilidade individual da condição larval, ou ainda a fatores como estresse causado às fêmeas ovígeras durante embriogênese.

Palavras-chave: comportamento, Callianassidae, desenvolvimento larval, inanição, lecitotrofia, Lepidophthalmus siriboia.

\section{REFERENCES}

Abrunhosa FA And Kittaka J. 1997a. Functional morphology of mouthparts and foregut of the last zoea, glau- cothoe and first juvenile of the king crab Paralithodes camtschaticus, P. brevipes and P. platypus. Fish Sci 63: 923-930.

Abrunhosa FA ANd Kittaka J. 1997b. Effect of starvation on the first larvae of Homarus americanus (Decapoda: Palinuridae). Bull Mar Sci 61: 73-80.

Abrunhosa FA, Melo MA And Abrunhosa JP. 2003. Development and functional morphology of the foregut of larvae and postlarva of Ucides cordatus (Decapoda, Ocypodidae). Nauplius 11: 37-43.

Abrunhosa FA, Pires MA, Lima JF and CoelhoFILHo PA. 2005. Larval development of Lepidophthalmus siriboia Felder and Rodrigues, 1993 (Decapoda: Thalassinidea) from the Amazon region, reared in the laboratory. Acta Amaz 35: 77-84.

Abrunhosa F, Melo M, Lima JF and Abrunhosa J. 2006. Developmental morphology of mouthparts and foregut of the larvae and postlarvae of Lepidophthalmus siriboia Felder and Rodrigues, 1993 (Decapoda: Callianassidae). Acta Amaz 36: 335-342.

ANGER K. 1995. Starvation resistance in larvae of a semiterrestrial crab, Sesarma curacaoense (Decapoda: Grapsidae). Jour Exp Mar Biol Ecol 187: 161-174.

ANGER K. 1996. Physiological and biochemical changes during lecithotrophic larval development and early juvenile growth in the Northern stone crab, Lithodes maja (Decapode, Majidae). Mar Biol 126: 283-296.

ANGER K AND DAWIRS RR. 1981. Influence of starvation on the larval development of Hyas araneus (Decapoda, Majidae). Helgol Meeres 34: 287-311.

ANGer K, Storch V ANd CApuzzo M. 1985. Effects of starvation on molt cycle and hepatopancreas of stage I lobster (Homarus americanus) larvae. Helgol Meeres 39: $107-116$.

Lima JF, Abrunhosa F And Coelho PA. 2006. The larval development of Pinnixa gracilipes Coelho (Decapoda, Pinnotheridae) reared in the laboratory. Rev Bras Zool 23: $480-489$.

Melo GAS. 1999. Manual de identificação dos Crustacea Decapoda do litoral brasileiro: Anomura, Thalassidinea, Palinuridea, Astacidea. Plêiade / FAPESP, São Paulo. p. $370-371$.

MCCONAUgha JR. 1985. Nutrition and larval growth. In: Wenner A (Ed), 2. Larval Growth. A.A. Balkema Rotterdan, p. 127-154.

NAtes SF And MCKenney-JR. CL. 2000. Ontogenetic changes in biochemical composition during larval and 
early postlarval development of Lepidophthalmus louisianensis, a ghost shrimp with abbreviated development. Comp Bioc Physi 127: 459-468.

RoDRIGUES SA. 1976. Sobre a reprodução, embriologia e desenvolvimento larval de Callichirus major Say, 1818 (Crustacea, Decapoda, Thalassinidea). Bol Zool 1: 85104.

SoKal RR And Rohlf FJ. 1995. Biometry. The Principles and Practice of Statistics in Biological Research, W.H. Freeman and Co, New York.
STRASSER KM AND FELDER DL. 1999. Larval development in two populations of the ghost shrimp Callichirus major (Decapoda: Thalassinidea) under laboratory conditions. Jour Crust Biol 19: 844-878.

Thessalou-Legaki M, Peppa A and Zacharaki M. 1999. Facultative lecithotrophy during larval development of the burrowing shrimp Callianassa tyrrhena (Decapoda: Callianassidae). Mar Biol 133: 635-642. 